Araștırma Makalesi / Research Article

\title{
Himaye-i Etfal Cemiyetinin Mali Durumu Hakkında Bir Değerlendirme
}

\author{
Büşra Karataşer* \\ (ORCID ID: 0000-0002-3208-657X) \\ Gönderim Tarihi \\ (Submitted) \\ 24.06.2020 \\ Kabul Tarihi \\ (Accepted) \\ 07.09.2020 \\ Yayın Tarihi \\ (Published) \\ 30.09 .2020
}

\section{Atıf Bilgisi/Reference Information}

Chicago: Karataşer, B., "Himaye-i Etfal Cemiyetinin Mali Durumu Hakkında Bir Değerlendirme", Vakanüvis-Uluslararası Tarih Araştırmaları Dergisi, 5/2 (2020): 736-758.

APA: Karataşer, B. (2020). Himaye-i Etfal Cemiyetinin Mali Durumu Hakkında Bir Değerlendirme. Vakanüvis-Uluslararası Tarih Araştırmaları Dergisi, 5 (2) , 736-758.

\section{Öz}

Çocuk dünyanın geleceği, bir toplumun en temel varlığıdır. Dünyada her ülke geleceklerinin teminatı olan çocukları korumak için bazı önlemler almıştır. Korunmaya muhtaç çocuk anne babası tarafından terk edilen, anne babası olmayan çocuk demektir. Osmanlı toplumunda çocuk konusunda özenle durulmuş çocukların korunması, bakımı, beslenmesi ve eğitimlerine mümkün olan ihtimam gösterilmiştir. Çocuklarla öncelikli olarak aile içerisinde ilgilenilmiştir Ailenin bulunmadığı durumlarda ise çocuğun bakım ve himayesi ailenin yakın çevresi tarafından sağlanması bir gelenektir.

Osmanlı toplumunda çocukların korunmasına yönelik ilk uygulamanın tereke defterleri olduğu bilinmektedir. Bu noktadan hareketle Osmanlı'da çocuk koruma konusundaki uygulamalara ilk defa tereke defterlerinde

* Dr. Öğr. Üyesi, Tekirdağ Namık Kemal Üniversitesi, İktisadi ve İdari Bilimler Fakültesi, îktisat Bölümü, Türkiye, bkarataser@nku.edu.tr.

PhD.- Faculty Member, Tekirdag Namık Kemal University, Faculty of Economics and Administrative Sciences, Department of Economics, Turkey.

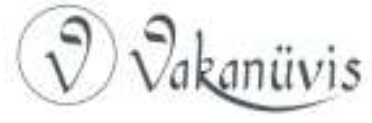


rastlamaktayız. Sonraki dönemlerde vakıflar ile korunmaya muhtaç çocuklara bakılıyordu.

Bu çalışma kimsesiz çocukları himaye etmek amacı ile kurulan Himaye-i Etfal Cemiyetinin kurulduğu dönemdeki şartları, ülkenin içinde bulunduğu koşulları, cemiyetin mali koşullarını iyileştirme çabasını gözler önüne sermek amacını taşımaktadır. Böyle bir müessesenin kurulmasını sağlayan sebep ise, toplumun içinde oluşan kimsesiz çocuklar ve bu çocukları kurtarma gayreti olmuştur.

Anahtar Kelimeler: Çocuk koruma,Himaye-i Etfal, Gelir, İstanbul ,Savaş

\section{An Evaluation of the Financial Situation of theHimaye-I Etfal Society}

\section{Abstract}

Child is the future of the world, the most basic being of a society. Every country in the world has taken some precautions to protect children, who are the guarantee of their future. A child in need of protection means a child who is abandoned by his or her parents and who doesn't have parents. In Ottoman society, the issue of children was carefully emphasized, possible attention was paid to the protection, care, nutrition and education of children. Children were primarily taken care of within the family. In cases where the family was not available, it was a tradition that the care and protection of the child was provided by the family's immediate circle.

It is known that the first application aimed at protecting children in Ottoman society was the inheritance notebooks. From this viewpoint, in the Ottoman, we first come across applications regarding child protection in inheritance notebooks. In the following periods, children in need of protection were cared for by foundations. In the following periods, children in need of protection were cared for by foundations.

This study aims to reveal the effort to improve the conditions in the period when Himaye-i Etfal Society established to protect the orphans was founded, country conditions, the financial conditions of the society. The cause for the establishment of such an foundation was the orphans and effort to save them.

Keywords: Child Protection, Himaye-i Etfal, Financial Situation, Istanbul. 


\section{Giriş}

Dünyada bütün ülkelerin en önemli varlığı çocuklardır. Çocuğa verilen önem aslında geleceğe verilen önemdir. Dünyada bütün ülkeler çocukların eğitimi, korunması bakımı konusu ile yakından ilgilenmişlerdir. ${ }^{1}$ Çocukların en iyi bakılıp korundukları yer ailedir. Geleneksel toplumlarda çocuklar öncelikle aile içinde korunmuşlardır. Ailenin olmadığı durumlarda ise çocukları himaye görevi ailenin yakın çevresi bu görevi yerine getirmiştir. ${ }^{2}$ Osmanlı Devletinde çocukların korumasına yönelik ilk adım miras bağlamında tereke kayıtlarının tutulmasıdır. Bu kayıtların tutulmasıyla birlikte doğmamış çocukların dahi hakkı korunmuş oluyordu. ${ }^{3}$ Osmanlı Devletinde yetimler ve muhtaç kimselerin korunması amacıyla birçok sosyal yardım kurumu kurulmuştur. Bu kurumların başında vakıflar gelmektedir. Tanzimat öncesi dönemde çocukların korunmasıyla özel olarak hizmet tanımlanmamışsa da vakıflar aracılığı ile direkt olarak yada hayır kurumlarında ihtiyaç sahiplerine temel ihtiyaçları karşılanıyordu. ${ }^{4}$

Osmanlı-Rus Savaşı sonrası mevcut Osmanlı şehirlerine kaybedilen bölgelerden göç eden Müslüman halkın serserilik, dilencilik, aylaklık gibi sosyal sorunlara sebep olduğu konusunda bir görüş hakim idi. ${ }^{5}$ Trablusgarp ve Balkan Savaşlarından sonra I.Dünya Savaşı gibi büyük bir savaşa katılan Osmanlı Devleti, bütün iş gücünü cephelere göndermiş ve bunların büyük bir çoğunluğu geri dönememiştir. Savaşa gidenlerin geride bıraktıkları bakıma muhtaç kimsesiz çocukların ihtiyaçlarının giderilmesini halkın çabalarıyla karşılamak yeterli değildi. ${ }^{6}$ Balkan Savaşlarından sonra muhacirlerin İstanbul'a gelip sığınmaları

${ }^{1}$ Kevser Şeker, Osmanlıdan Cumhuriyete Çocukların Korunması ve Çocuk Esirme Kurumu(1917-1981), Yayımlanmamış Yüksek Lisans Tezi, İstanbul,2015,s.17

2 Abdullah Karatay, Cumhuriyet Dönemi Korunmaya Muhtaç Çocuklara ilişkin Politikanın Oluşumu, Basılmamış Yüksek Lisans Tezi, İstanbul ,2007,s.100

${ }^{3}$ Nesimi Yazıcı, "Osmanlılarda Yetimlerin Korunması Üzerine Bazı Değerlendirmeler", Ankara Üniversitesi İlahiyat Fakültesi Dergisi, 2007,S.1,s.13

${ }^{4}$ Kevser Şeker, Osmanlıdan Cumhuriyete Çocukların Korunması ve Çocuk Esirme Kurumu(1917-1981), Yayımlanmamış Yüksek Lisans Tezi, İstanbul,2015,s.18

${ }^{5}$ Nazan Maksudyan," Evli evine köylü köyüne, evli olmayan Osmanlı Kent Reformu ve Şehirlerde İstenmeyen Çocuklar", Kebikeç,34 (2012),s.159.

${ }^{6}$ Makbule Sarıkaya, "Savaş Yıllarında Himaye-i Etfal Cemiyeti'nin Çocuk Misafirhanesi ve Çocuklar", Atatürk Üniversitesi Atatürk IIlkeleri ve Inkılap Tarihi Enstitüsü Müdürlüğü Atatürk Dergisi, 3, (2003), s.1

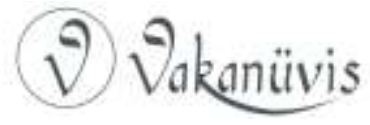


üzerine muhacir yetimlerin eğitim ihtiyaçlarının giderilmesi öncelikli konulardan biri olmuştur. Bu muhacirlerden Balkanlardan gelenlerin mal ve mülklerini terk ederek İstanbul'a gelip sığınmaları sebebi ile İskan-ı Aşayir ve Muhacirin Müdüriyeti konuyla ilgilenmiştir. Illk olarak şehit öksüz ve yetim çocuklarının eğitim konusuyla ilgilenilmiş ve ülkedeki sanayi okullarına yazı göndererek sanayi mekteplerinin kaç yetim öğrenci alacakları sorulmuştur. ${ }^{7}$

Osmanlı İmparatorluğunda muhtaç durumda olan çocukları korumak, meslek edindirmek amacıyla ıslahhaneler kurulmuştu. ${ }^{8}$ 1860'ların başında ilk ıslahhanelerin kurulmasından sonra imparatorlukta yirmi yıl içinde çok sayıda ıslahhane açılmış oldu. Planlı kentleşme, şehirde düzen sağlanması bunun yanında üretimde verimliliğin sağlanması gibi yeni söylemler gelişerek kurumsal yapıda değişikliklere ihtiyaç duyulduğu inancını artırıyordu. ${ }^{9}$

İkinci Abdülhamid döneminde yetim çocuklara meslek edindiren ilköğretim seviyesinde yatılı bir okul olan Darülhayr-ı Ali açılmıştır. Okul kuruluş sürecinin başında Darüleytam olarak adlandırılmışken isim değişikliğine gidilerek Darülhayr-ı Ali olmuştur. Darülhayr Vezneciler'de Zeynep Hanım Konağı'nda eğitime başlamıştır. Başkent İstanbul'da bazı gençlerin geçimlerini sağlayamadıkları ve bir kısım Müslüman çocukların sefil halde kalmaları padişah nezdinde hoş karşılanmamıştır. Bu şekilde olan çocukların hem ahlaki hem de ilmi eğitim almalarını sağlamak amacıyla Darülhayr'ın açılma amacı ifade edilmiştir. ${ }^{10} O$ kulun eğitim süresi bir yıl hazırlık olmak üzere yedi olarak tasarlanmıştı. Okul 40 erkek ve 40 kız öğrenci olmak üzere 80 talebeyle eğitim hayatına başlamıştı. Kurumun öğrenci sayısının kısa zaman içerisinde dört yüze ulaştığı ve talebe yetişebilmek için ek bir bina yapıldığı bilinmektedir. Talebe sayısının kısa sürede artması böylesi

7 Ebubekir Sofuoğlu, Osmanlı Devletinde Yetimler için Alınan Bazı Sosyal Tedbirler, Savaş Çocukları Öksüzler ve Yetimler, İstanbul,(2003),s.56

8 Büşra Karataşer," Konya Hamidiye Sanayi Mektebi", Kırklareli Üniversitesi iiBF Dergisi ,6/1(2017), s.127.

${ }^{9}$ Maksudyan, a.g.m, s.159.

10 Hikmet Zeki Kapcı," Osmanlı Eğitim Sisteminde Disiplin: Darülhayr-ı Ali Örneği ", Uluslar arası Sosyal Araştırmalar Dergisi,6/28 (2013), s.169.

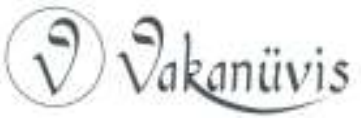


kurumlara ne kadar ihtiyaç duyulduğunu göstermektedir. ${ }^{11}$ Darülhayr ${ }^{\prime}$ da temel derslerin yanında marangozluk oyuncakçılık, seracılık, döşemecilik, bahçıvanlık, pastacılık, kunduracılık gibi dersler verilerek çocukların meslek öğrenmeleri amaçlanmıştır. ${ }^{12}$ Darülhayr'ın 1909 yılında lağvedilmesiyle birlikte öksüz,yetim çocukları himaye etmek için yeni kurumlara intiyaç duyulmaya başlanmıştı.

Bu çalışmada Himaye-i Etfal cemiyetinin hangi koşullarda açıldı̆̆ı, cemiyetin mali durumu, kurulma sebepleri çerçevesinden incelenecektir.

\section{Himaye-i Etfal Cemiyeti'nin Kuruluşu}

Himaye-i Etfal Cemiyeti'nin kuruluşundan bahsederken öncelikle cemiyetin kurulmasına zemin oluşturan etkenlerin değerlendirmek gerekir. Bu dönemde Anadolu'nun ve ülkenin sosyal ve iktisadi durumunun da incelenmesi gerekmektedir. Devlet savaş ekonomisi koşullarından maddi olarak yıpranmıştır. Osmanlı Devleti uzun süreli bir savaşa hazır değildi. 1914 yılından itibaren zirai verimlilik ise yüzde 13 civarındaydı. Ülke savaşa yeterli gıda stoğuyla girmiş ancak 1915 yılına gelindiğinde başta buğday olmak üzere birçok temel intiyaç maddesi arzında zorunlar yaşanmaya başlamıştır. ${ }^{13}$

Yaşanan savaşlar sonrası göç eden insan sayısı artmış ve yeni kurumlara intiyaç duyulduğu ortaya çıkmıştır. ${ }^{14}$ Gıda maddelerinde arzda meydana gelen azalmaya ve ülkenin işgaline bağlı olarak ulaşımın aksamasıyla birlikte gıda maddeleri fiyatlarında büyük bir artış söz konusu olmuştur. Öyle ki iç̧ Anadolu'dan İstanbul'a buğday ithal etmek New York'tan buğday ithal etmekten daha pahalıydı. Bu nedenle İstanbul hububat tüketimi Avrupa ve Amerika'dan gelen unlarla sağlanıyordu. ${ }^{15}$ Ekmek, şeker, et gibi gıda maddelerinde fiyat yükselmeleri ve ihtikar söz konusu olmuştur. Halk açlık, kıtlık ve

11 Nadir Özbek," II. Abdülhamid ve Kimsesiz Çocuklar Darülhayr-ı Ali, Tarih ve Toplum 182 (1999), s.17.

12 Hikmet Zeki Kapcı, Osmanlıdan Cumhuriyete Yetim, İstanbul,(2016),s.79.

${ }^{13}$ Vedat Eldem, Harp ve Mütareke Yıllarında Osmanlı Imparatorluğunun Ekonomisi, Ankara,1994,s.34

${ }^{14}$ Kevser Şeker, Osmanlıdan Cumhuriyete Çocukların Korunması ve Çocuk Esirme Kurumu(1917-1981),Yayımlanmamış Yüksek Lisans Tezi, İstanbul,2015,s.101

${ }^{15}$ Korkut Boratav, Türkiye iktisat Tarihi 1908-2015, Ankara, 2018,s.30

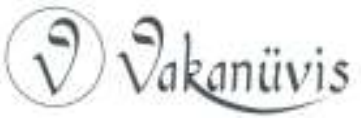


sefaletle mücadele etmiştir. ${ }^{16}$ Bunun yanında sağlık konusunda da eksiklikler bulunuyordu. Savaşlar sonucu ortaya çıkan hastalıklar ise çok sayıda insanın ölmesine sebep olmuştur. ${ }^{17} \mathrm{Bu}$ dönemde birçok çocuk gerek savaş gerek açlık, kıtlık sebebiyle kimsesiz kalmış, ülkenin her yerinde kimsesiz çocuk konusu büyük bir sorun olarak ortaya çıkmıştır. ${ }^{18}$

Kimsesiz, yardıma muhtaç çocukları himaye temek amacıyla Himaye-i Etfal Cemiyeti 1917 yılında kurulmuştur. Ancak İstanbul'da kurulan Himaye-i Etfal Cemiyeti'nden önce çocukların himayesi için Kırklareli'nde 1908 yılında bir cemiyet kurulmuştur. Bu cemiyet Dr. Fuad Umay tarafından kurulmuş olup 1917 yılında İstanbul'da kurulan Himaye-i Etfal cemiyetine katılmıştır. ${ }^{19}$

Cemiyete kabul şartları cemiyet nizamnamesine göre şu şekildedir. Cemiyete on üç yaşına kadar olan çocukların kabul edileceği, on üç yaşını geçenlerin ise Heyet-i Merkeziye'nin kararına göre kuruma kabul edileceği belirtilmiştir. Cemiyet çocuklara eziyet edilmemesi, bedeni ve ruhi gelişimini engellemeyecek şekilde hizmet ettirilmemesi istenmiştir. $^{20}$

\section{Cemiyetin Şubeleri}

Himaye-i Etfal Cemiyeti'nin İstanbul'da Beyoğlu, Beşiktaş, İstanbul, Haliç, Bakırköy, Üsküdar, Yeniköy, Büyükada ve Kadıköy olmak üzere dokuz şubesi bulunmaktadır. Merkezi İstanbul olmakla birlikte taşra da birçok şube açmıştır. Korunmaya muhtaç çocuk konusu ülkenin her yerinde büyük bir sorun olması sebebi ile ülkenin birçok bölgesinde Himaye-i Etfal Cemiyetinin şubeleri açılmıştır. ${ }^{21}$

\footnotetext{
16 Büşra Karataşer, 1914-1923 arası istanbul'un laşesi ve ihtikar Sorunu, Nobel Yayıncılık, Ankara,s.47-98

17 Makbule Sarıkaya, a.g.m., s.11

18 Burcu Deniz, Dr. Fuad Umay ve Çocuk Esirgeme Kurumu Faaliyetleri, Yayımlanmamış Yüksek Lisans Tezi, Kırklareli,2019,s.58

${ }^{19}$ Kevser Şeker, a.g.t.,s.104.

20 Abdullah Karatay, Cumhuriyet Dönemi Korunmaya Muhtaç Çocuklara ilişskin Politikanın Oluşumu, Basılmamış Yüksek Lisans Tezi, İstanbul ,2007,s.185

${ }^{21}$ Himaye-i Etfal Cemiyeti Umumi Rapor ve Bilanço, Matbaa-i Ahmed Ihsan ve Şürekası, İstanbul,1339,s.40-41
}

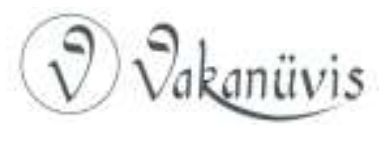


Tablo 1

Himaye-i Etfal Cemiyeti Şubeleri ve İdare Kurulları

\begin{tabular}{|c|c|c|}
\hline Şube İsmi & Kuruluş Tarihi & İdare kurulları \\
\hline Kırklareli & 20 Eylül 1917 & $\begin{array}{l}\text { Başkan Doktor Fuat Beyefendi, Katip Nazmi } \\
\text { Bey, Veznedar Cemal Bey [Kırklareli Şubesi } \\
\text { Babaeski, Mustafa Paşa, Pınarhisar ve Vize } \\
\text { kazalarılyla ve nahiyesinde birer bağı şube } \\
\text { açmıştır. }\end{array}$ \\
\hline Samsun & 12 Ekim 1917 & $\begin{array}{l}\text { Başkan Mahkeme Hakimi Nevzad Efendi, ikinci } \\
\text { Başkan Nazım Bey, Katip Şükrü Efendi, } \\
\text { Muhasebeci Vramidi Efendi }\end{array}$ \\
\hline Izmit & 27 Ekim 1917 & $\begin{array}{l}\text { Başkan Mutasarrıf ỉbrahim Süreyya Bey, ikinci } \\
\text { Başkan İsmail Hakkı Efendi, Katip Veysi Bey, } \\
\text { Muhasebeci Sıddık Bey, Veznedar Hidayet Bey }\end{array}$ \\
\hline Konya & 1 Ocak 1918 & $\begin{array}{l}\text { Başkan Vali Muammer Beyefendi, îkinci Başkan } \\
\text { Mektupçu Kemaleddin Bey, Katip Şinasi Bey, } \\
\text { Muhasebeci Adil Efendi, Veznedar Münir Bey }\end{array}$ \\
\hline İstanbul & 1917 & $\begin{array}{l}\text { Başkan Doktor Galip Hakkı Bey, Katip Seyfeddin } \\
\text { Bey (Bugün İstanbul Maliye Müfettişi), } \\
\text { Muhasebeci ve Veznedar Eczacı Beşir Kemal } \\
\text { Bey }\end{array}$ \\
\hline Üsküdar Şubesi & 1917 & $\begin{array}{l}\text { Başkan İstinaf Azasından Sabih Bey, Katip Faruk } \\
\text { Bey, Muhasebeci ve Veznedar Ahmed Refik Bey }\end{array}$ \\
\hline Beyoğlu Şubesi & 1917 & $\begin{array}{l}\text { Başkan Said Bey, Katip Kazım Refik Bey, } \\
\text { Muhasebeci ve Veznedar Nesim Ruso Efendi }\end{array}$ \\
\hline Haliç Şubesi & 1917 & $\begin{array}{l}\text { Kaymakam Arif Bey, Katip Said Bey, Muhsabeci } \\
\text { ve Veznedar Ali Bey }\end{array}$ \\
\hline Kadıköy Şubesi & 1917 & $\begin{array}{l}\text { Başkan Cemil Paşa, Katip Emin Bey, } \\
\text { Muhasebeci ve Veznedar Simonaki Efendi }\end{array}$ \\
\hline Bakırköy Şubesi & 1917 & $\begin{array}{l}\text { Başkan Hıfzı Paşa, Katip Babası Ziya Bey, } \\
\text { Muhasebeci ve Veznedar Haralambos Efendi }\end{array}$ \\
\hline
\end{tabular}




\begin{tabular}{|l|l|l|}
\hline Yeniköy Şubesi & 1918 & $\begin{array}{l}\text { Başkan Doktor İsmail Hurşid Bey, Katip } \\
\text { Abdurrahman Asım Bey, Muhasebeci ve } \\
\text { Veznedar Boyacıyan Efendi }\end{array}$ \\
\hline
\end{tabular}

Kaynak: Himaye-i Etfal Cemiyeti Umumi Rapor ve Bilanço, Matbaa-i Ahmed ihsan ve Şürekası, ìstanbul,1339,s.40-41

Cemiyetin İstanbul'da dokuz şubesi bulunmakla birlikte taşrada şubeleri bulunmaktadır. Bunlardan ilki Kırklareli'nde 1917 tarihinde kurulan şubedir. Bu şubenin de baba eski Mustafa Paşa, Pınarhisar ve Vize kazalarında bir şube açıldığı görülmektedir. Bu durum kimsesiz çocuk sayısının ne denli fazla olduğunun bir göstergesi olarak kabul edilebilir. Taşrada açılan bir diğer Şube ise Samsun'dadır. 12 Ekim 1917 tarihinde açılmıştır. Başkanı Nevzad Efendi'dir. Bir diğer şube ise İzmit şubesidir. İzmit Şubesi 27 Ekim 1917 tarihinde açılmıştır. Başkanı ise Ibrahim Süreyya Bey'dir. Bir diğer şube ise Konya'da açılmıştır. Reisi Vali Muammer Bey'dir.

İzmir ve İstanbul'un işgalinden sonra İstanbul'un diğer şehirlerle bağlantısı kesilmiştir. Bu sebeple heyet-i merkeziye tarafından alınan karar ile cemiyetin sadece Kadıköy şubesi görevine devam etmiştir.

Cemiyet bu şubelerden başka çeşitli tarihlerde Musul, Erzurum, Eskişehir, Kastamonu, Bolu merkezlerinde bazı şubeler açılmıştı. İzmir ve İstanbul'un işgalinden sonra cemiyetin şubeleri cemiyetin genel merkezi ile haberleşme imkanı kalmamış ve şubeler görevlerine devam edememişlerdir.

Himaye-i Etfal Cemiyeti'nin İstanbul şubesi ise 1919 yılında merkez kurulu tarafından İstanbul şubesinin gerekli fayda sağlayamadığı gerekçesi üzerine Kadıköy şubesi korunmasına karar vermişti. $^{22}$

\section{Kadıköy Şubesi'nin Faaliyetleri}

İstanbul Himaye-i Etfal Cemiyeti'nin İstanbul'daki faaliyetleri Kadıköy Şubesi tarafından gerçekleştirilmekteydi. Bu bölge dahilinde

${ }^{22}$ Himaye-i Etfal Cemiyeti Umumi Rapor ve Bilanço, İstanbul, Ahmed ihsan ve Şürekası, 1339, s.13

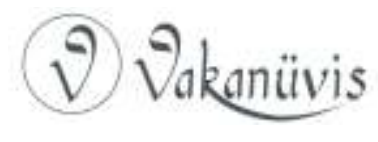


bulunan kimsesiz, öksüz ve yardıma muhtaç çocukların kimlik ve adresleri tespit edilerek bu çocuklara sürekli yardım sağlanmıştır. Annelerinin vefatı veya hastalığı sebebiyle inek sütü ile beslenmesi gereken çocuklara parasız süt tahsis ediliyordu. Bu konu da gazetelerce ilan olunmuştu. ${ }^{23}$

Tablo 2

Kadıköy Şubesi'nin 1921 Senesi Tahmini Gelir ve Harcamaları ${ }^{24}$

\begin{tabular}{|c|c|c|c|c|}
\hline \multicolumn{5}{|c|}{ Kadıköy Şubesinin Tahmini Gelirleri } \\
\hline Maaşları & Dökümü & & Maaşları & Dökümü \\
\hline Atölye müdiresi & 2000 & & Üye yıllık taahhütleri & 10.000 \\
\hline Katip & 1000 & & İaşe ve yatak taahhütlerinden & 50.000 \\
\hline Mürebbiye & 1000 & & & \\
\hline Hademe & 0500 & & & \\
\hline AşcI & 1000 & & & \\
\hline \multicolumn{2}{|l|}{ Harcamalar } & & \multicolumn{2}{|l|}{ Yardımlar } \\
\hline Yiyecekler & 135.000 & & $\begin{array}{llll}\text { Birinci sınıf } & \text { tüccar } & \text { ve } \\
\text { zenginlerden } & 20 & \text { kişiden } & 25 \\
\text { lira } & & & \end{array}$ & 50.000 \\
\hline Giyecekler & 62.500 & & $\begin{array}{llll}\text { İkinci sınıf } & \text { tüccar } & \text { ve } \\
\text { zenginlerden } & 13 & \text { kişiden } & 15 \\
\text { lira } & & & \end{array}$ & 45.000 \\
\hline $\begin{array}{l}\text { Aydınlatma, } \\
\text { sigorta, su, kira }\end{array}$ & 50.000 & 145.000 & $\begin{array}{lccc}\text { Üçüncü } & \text { sınıf } & \text { tüccar } & \text { ve } \\
\text { zenginlerden } & 50 & \text { kişiden } & 10 \\
\text { lira } & & & \end{array}$ & 0 \\
\hline Yakacaklar & 25.000 & & \multicolumn{2}{|l|}{ Yarışlar ve saire } \\
\hline $\begin{array}{l}\text { Tesisat ve atölye } \\
\text { malzemesi }\end{array}$ & 50.000 & & $\begin{array}{l}\text { Yarış yılda } 4 \text { kere } 525 \text { lira } \\
\text { hesabıyla }\end{array}$ & 210.000 \\
\hline
\end{tabular}

${ }^{23}$ Kevser Şeker, a.g.t. , s.126

${ }^{24}$ Himaye-i Etfal Cemiyeti Umumi Rapor ve Bilanço, İstanbul, Ahmed ìhsan ve Şürekası, 1339 , s.39. 


\begin{tabular}{|l|l|l|l|l|}
\hline $\begin{array}{l}\text { Temizlik ve temizlik } \\
\text { maddeleri }\end{array}$ & 15.000 & & $\begin{array}{l}\text { Sene başına devreden mevcut } \\
\text { para }\end{array}$ & 49.226 \\
\hline $\begin{array}{l}\text { Mutfak ve sefere } \\
\text { takımları }\end{array}$ & 15.000 & $\begin{array}{l}\text { Gerektiğinde merkez tesisat } \\
\text { karşıı̆ından }\end{array}$ & 35.774 \\
\hline $\begin{array}{l}\text { Muhtelif } \\
\text { harcamalar }\end{array}$ & 10.000 & & 500.000 & \\
\hline & & & 5 & \\
\hline
\end{tabular}

Kaynak: Himaye-i Etfal Cemiyeti Umumi Rapor ve Bilanço, İstanbul, Ahmed ìhsan ve Şürekası, 1339, s.39

Kadıköy şubesinin tahmini gelirlerine bakıldığında üyelerin yıllık taahhütleri, iaşe ve yatak taahhütleri, yardımlar, yarışlar vesaireden oluşmaktadır. Harcama kalemleri ise yiyecekler, giyecekler, aydınlatma, sigorta, su, kira, yakacaklar, tesisat ve atölye malzemesi ,temizlik ve temizlik maddeleri, mutfak ve sefere takımları,muhtelif harcamalardan oluşmaktadır. Gelen yardımlar ise zenginlerden gelen bağışlar, yapılan yarışlardan elde edilen gelirlerden oluşmaktadır. Cemiyetin gelirleri sınırlı olmakla birlikte giderlerinin çok sayıda kalemden oluştuğu görülmektedir. Cemiyet artan giderlerini karşılamak amacıyla yarış, yardım faaliyetleri düzenlemektedir.

Kadıköy Şubesi'nin 1922 Yılı Sonuna kadar Gelirler ve Giderler Hesapları ${ }^{25}$

Tablo 3 Kadıköy Şubesi 1922 Yılı Gelir Hesapları

\begin{tabular}{|c|c|c|c|}
\hline & $\begin{array}{l}\text { Miktar } \\
\text { kuruş }\end{array}$ & Santim & \\
\hline Merkezden & 10.000 & & \\
\hline $\begin{array}{l}\text { Bir prens Hanım tarafından süt } \\
\text { bedeli olarak }\end{array}$ & 21.227 & 50 & $\begin{array}{l}\text { Şubenin: } 1 \text { Ocak } 1922 \text { senesi } \\
\text { cetveli gereğince }\end{array}$ \\
\hline $\begin{array}{l}\text { Yardım karneleri ve üye } \\
\text { taahhütlerinden }\end{array}$ & 8.234 & & $\begin{array}{l}\text { Şubenin: } 1 \text { Ocak } 1922 \text { senesi } \\
\text { cetveli gereğince }\end{array}$ \\
\hline $\begin{array}{l}\text { Üye taahhütleriyle yarış } \\
\text { gelirlerinden }\end{array}$ & 49.395 & 75 & $\begin{array}{l}\text { Şubenin } 1 \text { Kasım } 1922 \text { senesi } \\
\text { cetveli gereğince }\end{array}$ \\
\hline
\end{tabular}

${ }^{25}$ Himaye-i Etfal Cemiyeti Umumi Rapor ve Blanço, İstanbul, Ahmed ihsan ve Şürekası, 1339 , s.70

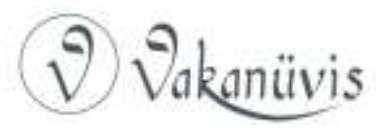




\begin{tabular}{|l|c|c|l|}
\hline Üye taahhütlerinden & 200 & & $\begin{array}{l}\text { Şubenin 30 Mayıs 1922 } \\
\text { senesi cetveli gereğince }\end{array}$ \\
\hline $\begin{array}{l}\text { 31 Aralık } 1922 \text { senesi cetveli } \\
\text { gereğince }\end{array}$ & 600 & & $\begin{array}{l}31 \text { Aralık } 1922 \text { senesi cetveli } \\
\text { gereği }\end{array}$ \\
\hline Toplam & $\mathbf{8 9 . 7 5 7}$ & $\mathbf{2 5}$ & \\
\hline
\end{tabular}

Kaynak: Himaye-i Etfal Cemiyeti Umumi Rapor ve Bilanço, İstanbul, Ahmed insan ve Şürekası, 1339, s.70

Kadıköy şubesinin 1922 yılı gelirlerine toplamı 89.757 kuruş 25 santimden ibarettir. Bu meblağın 10.000 kuruşluk kısmı merkezden gelmiş olup, 21.227 kuruş 50 santimlik kısmı ise bir prens tarafından çocuklara süt bedeli olarak verilmiştir. 8.234 kuruluk kısmı ise yardım karneleri ve üyelerin yıllık olarak ödemeyi taahhüt ettikleri miktardan oluşmaktadır. Gelirin en büyük bölümünü ise 49.395 kuruş ile üye taahhütleriyle yarış gelirlerinden oluşmaktadır. Kadıköy şubesi İstanbul'da bu dönemde açık kalan tek şubedir. İstanbul'da yardıma muhtaç bütün çocuklara Kadıköy şubesi hizmet etmektedir. En büyük gelir kalemi üye taahhüdü ve yarışlardan oluşarak cemiyetin ayakta durmasını sağlamaktadır.

Tablo 4 Kadıköy Şubesi 1922 yılı Giderleri

\begin{tabular}{|c|c|c|c|}
\hline & Miktar kuruş & Santim & \\
\hline $\begin{array}{l}\text { Kira, hademe } \\
\text { ücreti, süt bedeli }\end{array}$ & 22.010 & 75 & $\begin{array}{l}\text { Şubenin } 14 \text { Aralık } 1922 \text { senesi } \\
\text { cedveli gereğince }\end{array}$ \\
\hline $\begin{array}{l}\text { Kira, okul kitapları } \\
\text { ve süt bedeli ve } \\
\text { saire }\end{array}$ & 15.906 & 25 & $\begin{array}{l}\text { Şubenin } 1 \text { Kasım } 1922 \text { senesi } \\
\text { cedveli gereğince }\end{array}$ \\
\hline \multirow{2}{*}{$\begin{array}{l}\text { Süt bedeli, } \\
\text { çocuklara ayakkabı } \\
\text { ve kitap ücreti }\end{array}$} & 2585 & - & $\begin{array}{l}\text { Şubenin } 31 \text { Aralık } 1922 \text { senesi } \\
\text { cedveli gereğince }\end{array}$ \\
\hline & 40.582 & & \\
\hline $\begin{array}{l}1923 \text { yılı başında } \\
\text { devreden para }\end{array}$ & 19.175 & 25 & \\
\hline toplam & & & $\begin{array}{l}1922 \text { Yılı Ocak ayı başından } \\
\text { devreden para }\end{array}$ \\
\hline Vezne mevcudu & 47.538 & 75 & \\
\hline $\begin{array}{ll}\text { İtibar-ı } & \text { Milli } \\
\text { Bankasındaki } & \\
\text { mevcut } & \end{array}$ & 703.000 & & \\
\hline
\end{tabular}




\begin{tabular}{|l|c|l|l|}
\hline $\begin{array}{l}\text { Kadıköy } \\
\text { Şubesindeki } \\
\text { mevcut }\end{array}$ & 49.175 & 25 & \\
\hline & 797.714 & & \\
\hline
\end{tabular}

Kaynak: Himaye-i Etfal Cemiyeti Umumi Rapor ve Blanço, istanbul, Ahmed ihsan ve Şürekası, 1339 , s.70

Kadıköy şubesinin 1922 yılı harcama bütçesi ise 89.757 kuruştan oluşmaktadır. Kira, hademe ücreti, süt bedeli 22.010 kuruş 75 santimdir. Kira, okul kitapları ve süt bedeli vesaire ise 15.906 kuruş 25 santimdir. Süt bedeli, çocuklar ayakkabı ve kitap ücreti ise 2.585 kuruştur. Kadıköy şubesinin giderleri çocukların temel ihtiyaçları ve şubenin kira, hademe ücreti gibi sabit ödemelerinden kaynaklanmaktadır.

Himaye-i Etfal Cemiyeti başlangıçta, cins, mezhep, milliyet ayrımı yapmaksızın yardıma muhtaç tüm çocuklara hizmet etmek maksadı ile kurulmuştu. Mondros Mütarekesinden sonra ise gayrimüslim çocuklar kendi cemiyetleri tarafından himaye edilmeye başlanmıştır. Bu sebeple Himaye-i Etfal Cemiyeti Müslüman çocuklara hizmet veren bir kurum haline gelmiştir.

\section{Himaye-i Etfal Cemiyeti'nin Mali Durumu}

Himaye-i Etfal Cemiyetinin Nizamnamesine göre kurumun bütçesinde gelirleri şu şekildeydi; Üyelerin senelik aidat ödemeleri, hükümetin ve belediye dairelerinin tahsisatı, emval ve emlakının gelirleri, mevcut nakitlerin faizleri, düzenleyeceği sergi, müsamere, gezi, konferans, çiçek satışı ve diğer düzenleyeceği faaliyetlerden elde edilen hasılat, bağış, yardımlar. ${ }^{26}$

Himaye-i Etfal Cemiyeti 1917 yılında açılmış olmakla birlikte kimsesiz çocuk sayısının fazla olması sebebi gelirleri zaman içerisinde çocukların ihtiyaçlarını karşılamakta yetersiz kalmıştır. Cemiyet çocukların intiyaçlarını karşılamak amacı ile gelirlerini artırma yoluna

${ }^{26}$ Himaye-i Etfal Cemiyeti Umumi Rapor ve Bilanço, ,'istanbul, Ahmed ihsan ve Şürekası, 1338, s.3-4

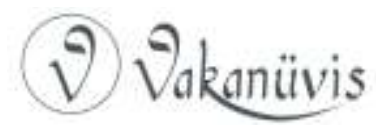


gitmiştir. Bu amaçla çeşitli konser, sergi, tiyatro düzenleyerek gelirlerini artırma yoluna gitmiştir. ${ }^{27}$

Cemiyet gelirlerini artırmak çeşitli yollara başvurmuştur.1921 yılında alınan bu önlemlerden bazıları şunlardır: Misafirhaneyi gerçek bir depo haline getirmek için çocukları ailelerin yanına ve özellikle fabrikalara, kurumlara ve ticarethanelere yerleştirmeye devam etmek, çocuklara ait bir ìktisat Sandığı kurmak için işin erbabına başvurmak, satış barakaları kurmak,sütçülükten başka tavukçuluk şubesi kurularak gelir elde etmek, Teşkilat-ı Mahsusa kanalıyla ayni yardımlar toplamak, İslam topluluğu aracılığıyla çocuk sadakası teşkilatına başvurmak, mevcut çocukları yavaş yavaş misafirhanedeki hizmetlere alıştırıp, giderlerin azalmasını sağlamak. ${ }^{28}$

Cemiyetin 1922 yılında ise gelirlerini artırmak için çeşitli yollara başvurmuştur. ${ }^{29}$

1. Çocukların sağlıklarının tam olarak korunabilmesi için seyyar bir müze düzenleyip kurulması,

2- Kalender Ziraat Yurdu'nun cemiyete devrinin sağlanması,

3- Türk Pazarı kurulması, ${ }^{30}$

4- Mevcut eşyanın tombala yoluyla satılması,

5- Çocukların sanat öğrenmesine teşvik,

6- Kamplar kurarak çocukların sağlık yönünden takviyesine çalışılması,

7- Üstün yetenekli çocukların yatılı okulları kaydı,

8- Bir bando oluşturulması,

9- Şubelerin canlandırılması ve sayılarının çoğaltılması,

10- Yeni gelir kaynakları sağlamak amacıyla vakıflar ve sair kurumlardan yardım toplayarak gelirlerin artırılması,

27 Büşra Karataşer, "Himaye-i Etfal Cemiyeti'nin Gelirleri Üzerine Bir Değerlendirme", Tarih Araştırmaları, Mart (2020),s.551-568

28 Himaye-i Etfal Cemiyeti Umumi Rapor ve Bilanço, 1337,s.18

${ }^{29}$ Himaye-i Etfal Cemiyeti Umumi Rapor ve Bilanço, 1337,s. 28

${ }^{30}$ Türk Pazarı için ayrıntılı bilgi için, Karataşer,a.g.m., s.556

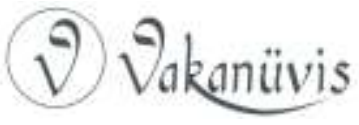


11- Çocukların vesayet kanununun yürürlüğe konulması için gerekli girişimlerde bulunulması.

Cemiyet 1922 yılında "Hıfzıssıhha-iEtfal Müzesi" (Çocuk Sağlığını Koruma Müzesi) açmıştır. Bu sağlık müzesinin açılmasının sebebi ise ülkemizde ve dünyada özellikle savaşlar sonrasında ölümler özellikle de çocuk ölümleri artmıştır. Bu durum nüfus siyasetini de önemli ölçüde etkilemiştir. Cemiyet tarafından çocuk ölümlerini azaltmak amacı ile hıfzıssıhhanın neşir ve ilanının etkisinin önemli olduğu düşünülmektedir. Bu sebeple halk arasında sağlık açısından çocuk büyütmek konusunda yanlış bilinen bilgileri değiştirmek için çeşitli önlemler alınmalıdır. Batılı ülkelerde halk sağlığını korumak amacı ile sinema filmleri çekilmektedir. Özellikle yeni doğan çocuklara bakım yolları isimli filmler çekilere toplum sağlığı korunmaya çalışıımıştır. Cemiyet ayrıca bu dönemde kalende yurdunun devrini sağlamış, eşyaları tombala yoluyla satarak gelir sağlamış, şube sayısını artırarak gelir sağlamıştır. ${ }^{31}$

\section{Himaye-i Etfal Cemiyeti'nin Yurt Dışında Başvurduğu Kuruluşlar ve Katılım Çabaları}

Cemiyet dünyada çocuk koruma faaliyetlerini yakından öğrenmek ve bu kuruluşlarla iş birliği yaparak çocuk koruma faaliyetlerini uluslar arası düzeyde yürütmek istemiştir.

Cemiyet yardım almak maksadı ile Etfale Muavenet-i Beynelmilel Heyet-i İttihadiyesi (Çocuklara Yardım Uluslararası Birleşik Komisyonuna başvurmuştur. Bu kurum uluslar arası nitelikte olup dünyadaki ülkelerin çocuk koruma konusunda nasıl mücadele ettiklerini de göstermektedir. 25 Şubat 1920 tarihinde Lozan'da Etfale-i Muavenet-i Beynelmilel Heyet-i İttihadiyesi Kongresi Cenevre'de düzenlenmiştir. Bu kongreye ülkemizden o tarihte Cenevre'de bulunan Ahmet Cevdet Beyefendi aracilı̆ıyla Zühdü Bey murahhas olarak seçilmiştir. Türkiye'deki Himaye-i Etfal Cemiyeti'nin çocuk koruma konusundaki faydalı bilgiler anlatılmıştır. Böylece Avrupa'lı devletlerle ilk defa çocuk koruma konusunda irtibata geçilmiştir. Dünyadaki yetim çocukların sayıları ve ihtiyaçları tespit edilmiştir.

${ }^{31}$ Himaye-i Etfal Cemiyeti Umumi Rapor ve Bilanço , 1338,s.13-14

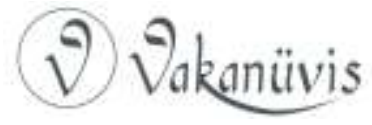


10 Ağustos 1920 tarihinde Himaye-i Etfal Cemiyeti aracılığıyla Başkan Profesör Dr. Besim Ömer Paşa ve Başkan Vekili Orfanidis Efendi, Dr. Rasim Ferid, Doktor Nurettin Rahmi beyler ve Hilal-i Ahmer'den Profesör Doktor Akil Muhtar, Hasan Tahsin, Doktor Hikmet ve Haydar beylerden oluşan bir kurul oluşturulmuştur. Bu kurul "Etfâle Mu'âvenet-i Beynelmilel Heyet-i İttihâdiyesi Türk Komitesi" adını almış ve bu şekilde Cenevre'de toplanan Heyet-i İttihadiye genel merkezine 3 Ekim 1920 tarihinde resmen bağlanmıştır. Bu komite vasıtasıyla Çocuklara Yardım Uluslararası Birleşik Komisyonuna başvuru yapılmıştır. Heyet-i İttihâdiyesi" merkezinden ilk kez gönderilen arpa kırması, süt, fasulye, pirinç ve kakao gibi maddelerle çeşitli giyilmiş elbiseler gönderilmiştir. Gönderilen bu eşyalar Kadıköy'de 1515, Kasımpaşa'da 1050,Topkapı'da 900,İstanbul'da 490, Beykoz'da 475, Hilal-i Ahmer Darussanaası'nda 130, Beylerbeyi'nde 20 olmak üzere toplan 4370 çocuğa cemiyet delegelerinin huzurunda cemiyet tarafından dağıtılmıştır. Bundan başka geçen sene sonlarında "Etfâle Mu'âvenet-i Beynelmilel Heyet-i İttihâdiyesi" nin bir ana şartı olan Londra'daki Etfâle Muavenet Cemiyeti tarafından Mistager adında gönderilen kişinin beraberinde bir hayli yüklü kumaş getirilmişti. Bu kumaşlar Hilal-i Ahmer Cemiyeti Hanımlar Darussanaası'nda dikilmiş ve muhacir çocuklarına dağıtılmıştır. ${ }^{32}$ Himaye-i Etfal Cemiyeti'nin uluslar arası kurumlarla işbirliği kurmasıyla birlikte yardım alarak ülkesindeki çocuklara yardım sağlamıştır.

\section{Cemiyetin Yardım İçin İslam Ülkelerine Başvurması}

Cemiyet Avrupa'daki Çocuklara Yardım Uluslar arası Birleşik Komisyonuna yaptığı başvuru sonrası ülkedeki çocuklara birçok eşyanın gelmesini sağlamıştır. Yardım istemek maksadı ile bu sefer Müslüman ülkelere başvuruda bulunmuştur.

Cemiyet gelişmiş ülkelerin benzer kuruluşlarıyla çocuklara yardım için girişimlerde bulunmakla birlikte bütün Müslümanların çocuk koruma konusuyla ilgili samimi bir şekilde ilgilenmeleri gerektiğini düşünerek bir mesaj hazırlamıştır. Bu mesaj Türkçe; Arapça ve Farsça dilerliyle yayınlanmıştır. ${ }^{33}$

${ }^{32}$ Himaye-i Etfal Cemiyeti Umumi Rapor ve Bilanço , 1338,s.13-14

33 Himaye-i Etfal Cemiyeti Umumi Rapor ve Bilanço, 1338,s.16

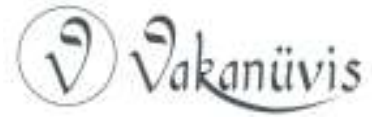


“Mısırlı ve Hindli kardeşlerimize

Hayat dağıtan mübarek Nil Nehri'nin yeşillenen Mısır kıtasında [insanlığın mukaddes beşiği olan Hind diyarında] naz ve nimetlerle beslenen sevgili din kardeşlerimize selam olsun!

Bizler ki küçük yaşta anasız babasız kalmış ve ancak kaderin bir lütfuyla İstanbul'a can atıp "Türk Himaye-i Etfal Cemiyeti"nin şefkat ve merhamet kanatlarının altına sığınmış Müslüman yetimleriyiz. Siz imanlı ve hamiyetli, cömert ve merhametli kardeşlerimize bu açıklamalarımızla yaralı kalplerimizi açıyoruz. Bu kardeş sesine kulak veriniz!

Sizlere bu hitap ve müracaatımız, din ve devlet uğruna şehit düşen Türk ve Müslümanların, o İslam fedaisi kahramanların savaş yüzünden harap ve toprak olan memleketimizde darmadağın, aç, susuz ve çıplak dolaşan oğulları ve kızcağızları, evet o kimsesiz masumlar sürüsü içindir.

Nihayet hayırsever insanların azimli ve şefkatli elleriyle selamet sahiline çekilmiş, barınacak, yiyecek bir parça ekmek ve maddi ve manevi her türlü yardım bulmak şansını yakalamış olan bizim, o mübarek ellerin erişemediği, yetişemediği yüzbinleri geçen mazlum ve perişan kardeşlerimizi düşünmemek, aramamak ve zavallıcıkların ne eziyetler ve sefaletler içinde çırpındıklarından siz Müslüman kardeşlerimizi haberdar etmemek elimizden gelmez. Bunun içindir ki aziz ve sevgili kardeşlerimiz, size bu satırları yazıp gönderiyoruz ve ümit ediyoruz ki burada lütuf ve yardımlarının minnettarı olduğumuz Türk zengin evlatlarının yardımları toplamını milyonlarca Mısırlı (Hindli) kardeşlerimizin gönüllerinden kopup toplanacak olan paralar yeterli miktara varacak ve o zaman yuvasız, okulsuz hiçbir yetim çocuk kalmayacaktır. Bizleri memnun etmek isterseniz, işte kardeşler harçlığınızdan böyle öksüz hakkı ayırıp biriktiriniz ve biriktirdikçe baba ve annelerinize verip deyiniz ki: Türkiye'deki gözleri yaşlı ve kalpleri yaralı Müslüman küçük kardeşlerimize verilmek üzere bu hediyelerimiz "Himaye-i EtfalCemiyeti" ne aittir.

Ey olgunluklar beşiği olan mübarek Mısır diyarı (Hind diyarı) sevgili din kardeşlerimiz, sizlere can ve gönüllerimizden tekrar tekrar binlerce ve binlerce selam!"

Hind büyüklerinden Hilafet Komitesi Başkanı Çotani tarafından Başkanı Besim Ömer Paşa önderliğinde 13 Temmuz 19212862 lira

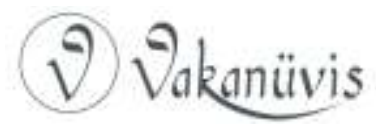


göndermişlerdir.15 Mart 1922 tarihinde iseTevfik Paşa vasıtasıyla da 2000 lira cemiyete teslim edilmiştir.

\section{Cemiyete Ayni Yardımda bulunanlar}

Cemiyete maddi yardım dışında birçok kişi veya kurum tarafından da iaşe masraflarını karşılama, yatak vermeyi taahhüd edenler olmuştur.

\section{Tablo 5}

Cemiyete Yardım Amacıyla Yatak taahhüdünde bulunanlar Cemiyetin Umumi Raporlarına Göre Cemiyete Yardım Amacıyla Yatak verme Taahüdünde Bulunanlar 1919-1920 ${ }^{34}$

\begin{tabular}{|l|l|l|l|}
\hline Kişi Adı & Tarih & $\begin{array}{l}\text { Yatak } \\
\text { adedi }\end{array}$ & $\begin{array}{l}\text { Yatak } \\
\text { Meblağı }\end{array}$ \\
\hline $\begin{array}{l}\text { Merhume Tahsife Ömer Şevki } \\
\text { Hanımefendi adına Besim Ömer Paşa } \\
\text { Hazretleri }\end{array}$ & 27 Mayıs 1919 & 1 & 2500 \\
\hline Rençberler Anonim Şirketi tarafından & 15 Haziran 1919 & $2-3$ & 5000 \\
\hline $\begin{array}{l}\text { İsmail Derviş Bey adına oğulları Mecdi ve } \\
\text { Celal Derviş Beyefendiler }\end{array}$ & 15 Haziran 1919 & 4 & 2500 \\
\hline $\begin{array}{l}\text { Mustafa Şamil Anonim Şirkete } \\
\text { tarafından }\end{array}$ & 15 Haziran 1919 & 5 & 2500 \\
\hline İntibah Mahfili adına Faik Sabri Bey & 24 Haziran 1919 & 6 & 2500 \\
\hline $\begin{array}{l}\text { Fabrikatör Duhani merhum Hacı Hüseyin } \\
\text { Efendi }\end{array}$ & 24 Ağustos 1919 & 7 & 2500 \\
\hline $\begin{array}{l}\text { Saygın Tüccarlardan Osman Ziver Efendi } \\
\text { zevcesi merhûme Safiye Hanım } \\
\text { tarafından }\end{array}$ & 31 Ağustos 1919 & 8 & 2500 \\
\hline İstanbul Muhafızı Said Paşa Hazretleri & 24 Aralık 1919 & 9 & 2500 \\
\hline $\begin{array}{l}\text { Saygın Tüccarlardan Balcı-zâde Ibrahim } \\
\text { Beyefendi }\end{array}$ & 28 Şubat 1920 & 10 & 2500 \\
\hline Profesör Nahidoseni & 28 Şubat 1920 & 11 & 2500 \\
\hline $\begin{array}{l}\text { Kont Kabrini KaranibeRödayal Miralay } \\
\text { Polis Delegesi }\end{array}$ & (28 Şubat 1920 & 12 & 2500 \\
\hline Profesör Netsenzöfao & (28 Şubat 1920) & 13 & 2500 \\
\hline Kadıköy Gaz Şirketi adına Direktör & 16 Mart 1920 & 14 & 2500 \\
\hline Tüccar Sarim Beyefendi & 16 Mart 1920 & 15 & 2500 \\
\hline
\end{tabular}

${ }^{34}$ Himaye-i Etfal Cemiyeti Umumi Rapor ve Bilanço, 1338,s.9-10

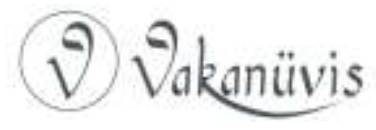




\begin{tabular}{|c|c|c|c|}
\hline Dilber-zâde Beyler Ticarethanesi & 16 Mart 1920 & $16-17$ & 500 \\
\hline Rifatzade Beyler Ticarethanesi & 16 Mart 1920 & 18 & 2500 \\
\hline İsmail Recep Bey Ticarethanesi & 16 Mart 1920 & 19 & 2500 \\
\hline Ekrem Necip Beyler Ecza Deposu & 16 Mart 1920 & 20 & 2500 \\
\hline $\begin{array}{l}\text { İtalyan Kumandanlarından Mösyö Radar } \\
\text { Cenapları }\end{array}$ & 5 Nisan 1920 & 21 & 2500 \\
\hline $\begin{array}{llcc}\text { Kavalalı Ahmed Bey-zâde } & \text { Mısırlı } \\
\text { Merhûm Hüseyin Galip Paşa } & \text { adına } \\
\text { kerimeleri Kerime Hanımefendi } & \\
\end{array}$ & 24 Nisan 1920 & 22 & 2500 \\
\hline $\begin{array}{l}\text { Bir cemiyet-i hayriye adına Orhan Tahsin } \\
\text { Beyefendi }\end{array}$ & 29 Nisan 1920 & 23 & 2500 \\
\hline $\begin{array}{l}\text { Arif Pertutlu Bey'in kerimesi merhûme } \\
\text { Tuhaf Hanım adına }\end{array}$ & 8 Haziran 1920 & 24 & 2500 \\
\hline Osmanlı İtibar-ı Milli Bankası tarafından & 14 Haziran 1920 & $\begin{array}{l}25,26 \\
27,28\end{array}$ & 10.000 \\
\hline $\begin{array}{l}\text { Osmanlı İtibar-ı Milli Bankası Umum } \\
\text { KatibiSubhi Beyefendi }\end{array}$ & 14 Haziran 1920 & 29 & 2500 \\
\hline Kont Şaban Lapalis Hazretleri & 27 Haziran 1920 & 30 & 2500 \\
\hline Mösyö MarselSaltiyel & 15 Temmuz 1920 & 31 & 2500 \\
\hline KridiFonise de NoltoziEdalzeremi & 15 Temmuz 1920 & 32 & 2500 \\
\hline
\end{tabular}

Kaynak : Himaye-i Etfal Cemiyeti Umumi Rapor ve Bilanço, 1338,s.9-10

Himaye-i Etfal Cemiyetine çocuklarının barınma masraflarını karşılamak maksadı ile yatak taahhüdünde bulunanların sayısı 32 kişidir. Bu kişilerin kimi yabancı uyruklu kimi ise Osmanlı eşrafındandır. Çocukları himaye etme konusunun evrensel olması sebebi ile toplumun her kesiminden çocuklara yardım edilmiş ihtiyaçları karşılanmıştır.

\section{a)1922 Yılında Yatak Taahhüdünde Bulunan Kişiler}

1919-1920 yıllarında yatak taahhüdünde bulunanlar olduğu gibi 1922 yılında da çocukların yatak, barınma ihtiyaçları karşılanmıştır. Bir yetimin yıllık ve yatak masrafı 22,5 liradan ibaret olup yetim çocukların bu ihtiyaçlarını karşılayan isimler ise şunlardır:

Validesi Merhume Afife Hanım adına Doktor Besim Ömer Paşa, Babası merhum Ömer Şevki Paşa adına Doktor Besim Ömer Paşa, Şamlı Ticarethanesi Saygın tüccarlardan Osman Ziver Efendi,istanbul Muhafızı Said Paşa, Saygın tüccarlardan Balcı-zâde İbrahim Bey,

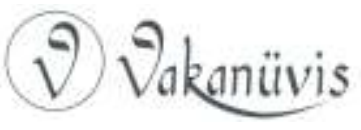


Profesör Gdoseni, Kont Kaprini, KarabineRovayal, Miralay Polis Delegesi, Profesör Vensenezufau,Kadıköy Gaz Şirketi adına, Saygın tüccarlardan Kibar Sarim Bey, Saygın tüccarlardan Dilber-zâde Beyler,Ekrem Necip Bey, İtalyan Kumandanlarından Mösyö Dar, Kavalalı Ahmed Bey-zâde Mısırlı merhum Hüseyin Galip Paşa adına kızları Kerime Hanımefendi,Bir hayır cemiyeti adına Doktor Orhan Tahsin Bey,Kont Şaban Lapalis, Kredi Fotsie de TonoziEdaljeri Bankası, Merhum pederleri Hacı Tahir Bey'le vâlidesi Nafia Hanım adına kızları Hatice Agah Hanımefendi, Merhum Şeyhülislam Cemaleddin Efendi eşleri Hadicetüzzehra Hanım adına oğulları Muhtar Beyefendi, Merhum Şeyhülislam Cemaleddin Efendi adına oğulları Muhtar Beyefendi,Seyr-i Sefain Genel Müdürü Hüseyin Bey,Hilal-i Ahmer Hanımlar Darussanaası, Bir hayır cemiyeti adına Fuat Hulusi Bey, Girid Kandiye tüccârından bir zat, Kadıköy Gaz Şirketi adına Saygın tüccarlardan Kibar Sarim Bey, Saygın tüccarlardan Dilber-zâde Beyler, Ekrem Necip Bey, Hilal-i Ahmer Hanımlar Darussanaası,Londra'da Oxford Üniversitesi Edebiyat Öğretmeni Ali Rıza Beyefendi'dir.

\section{b)iaşe(Beslenme) Yardımında Bulunanlar}

1922 yılında Himaye-i Etfal Cemiyetinde bulunan çocukların iaşeleri birçok kişi tarafından günlük olarak karşılamıştır. Çocukların yemek harcamalarını üstlene kişilerin isimleri ve kaç günlük yardımda bulundukları aşağıdaki listede belirtilmiştir. ${ }^{35}$

\section{Tablo 5}

1922 yılı Himaye-i Etfal Cemiyetine Çocukların Birden On Güne kadar Yemek Harcamalarını Üstlenenler

\begin{tabular}{|c|c|c|c|}
\hline Kişilerin isimleri & $\begin{array}{l}\text { l̇aşe } \\
\text { Sağlayacakları } \\
\text { Gün Sayısı }\end{array}$ & Kişilerin isimleri & $\begin{array}{l}\text { İaşe } \\
\text { Sağlayacakları } \\
\text { Gün Sayısı }\end{array}$ \\
\hline $\begin{array}{lrr}\text { Eski Hidiv } & \text { Merhum } \\
\text { İsmail Paşa } & \text { kızı } \\
\text { Prenses } & \text { Emine } \\
\text { Hanımefendi } & \end{array}$ & 10gün & $\begin{array}{ll}\text { Hasan Amir Bey'in } \\
\text { Eşleri } & \text { Hatice } \\
\text { Hanımefendi } & \end{array}$ & 1 gün \\
\hline $\begin{array}{lr}\text { Merhum } & \text { peder ve } \\
\text { valideleri } & \text { adına }\end{array}$ & 3 gün & $\begin{array}{ll}\text { Babaları Hasan Amir } & \text { Adile }\end{array}$ & 1 gün \\
\hline
\end{tabular}

${ }^{35}$ Himaye-i Etfal Cemiyeti Umumi Rapor ve Bilanço, 1338,s.22-23

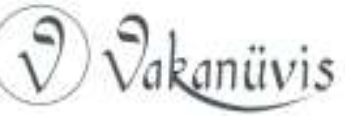




\begin{tabular}{|c|c|c|c|}
\hline $\begin{array}{l}\text { Doktor Besim Ömer } \\
\text { Paşa }\end{array}$ & & Hanımefendi & \\
\hline $\begin{array}{l}\text { Merhum Atıf, Osman } \\
\text { Tevfik beyler adına } \\
\text { Ekrem Beyefendi }\end{array}$ & 2 gün & $\begin{array}{l}\text { Sıdıka Hanım adına } \\
\text { Kıdemli Yüzbaşı Hamdi } \\
\text { Efendi }\end{array}$ & 1 gün \\
\hline $\begin{array}{l}\text { Namık Paşa kızı } \\
\text { merhume Hatice } \\
\text { Hanım adına Harem } \\
\text { Şükrü Hanımefendi }\end{array}$ & 1 gün & $\begin{array}{l}\text { Merhûm Hüseyin Fevzi } \\
\text { Paşa adına eşleri Hatice } \\
\text { İsmeti Hanımefendi }\end{array}$ & 1 gün \\
\hline $\begin{array}{lr}\text { Kocası } & \text { merhum } \\
\text { Hamdi Bey } & \text { adına } \\
\text { Naile } & \text { Hamdi } \\
\text { Hanımefendi } & \\
\end{array}$ & 1 gün & $\begin{array}{l}\text { Merhum Bedriye } \\
\text { Hanım adına kız } \\
\text { kardeşleri Mihriban } \\
\text { Leyla Hanımefendi }\end{array}$ & 1 gün \\
\hline $\begin{array}{lr}\text { Kız kardeşi } & \text { Vahide } \\
\text { Hanım } & \text { adına } \\
\text { VerdinazRifat } & \\
\text { Hanımefendi } & \end{array}$ & 1 gün & $\begin{array}{l}\text { Merhum Ali Sami Bey, } \\
\text { Merhume Münire } \\
\text { Fevziye hanımlar adına } \\
\text { Fethiye Reşid } \\
\text { Hanımefendi }\end{array}$ & 1 gün \\
\hline $\begin{array}{l}\text { Babaları merhum } \\
\text { Nuri Paşa adına Eşref } \\
\text { Cevad Hanımefendi }\end{array}$ & 1 gün & $\begin{array}{ll}\text { Merhume } & \text { kızları } \\
\text { Nermin Hanım adına } \\
\text { Doktor Nureddin Rasih } \\
\text { Bey } 1 \text { gün }\end{array}$ & 1 gün \\
\hline $\begin{array}{lrr}\text { Babaları } & \text { merhum } \\
\text { Rifat Paşa adına } & \text { kızları Refia } & \text { İzzet } \\
\text { Hanımefendi } & \\
\end{array}$ & 1 gün & $\begin{array}{l}\text { Lebibe Amir } \\
\text { Hanımefendi }\end{array}$ & 1 gün \\
\hline $\begin{array}{l}\text { Mevhibe Münir } \\
\text { Hanımefendi, Fethiye } \\
\text { Reşid Hanımefendi } \\
\text { önderliğiyle }\end{array}$ & 2 gün & $\begin{array}{lr}\text { Merhum Samim Bey } \\
\text { adına } \\
\text { MünifeHanımefendi }\end{array}$ & 1 gün \\
\hline $\begin{array}{l}\text { Eczacı Edhem Pertev } \\
\text { Beyefendi oğlu Fehmi } \\
\text { Bey adına }\end{array}$ & 1 gün & $\begin{array}{l}\text { Merhum Seyfullah Paşa } \\
\text { adına kızları } \\
\text { hanımefendi } 1 \text { gün }\end{array}$ & 1 gün \\
\hline $\begin{array}{lr}\text { Saygın } & \text { ticaret } \\
\text { adamlarından } & \text { Taşcı- } \\
\text { zâde Hilmi Beyefendi }\end{array}$ & 1 gün & $\begin{array}{l}\text { Eleberu Hanımefendi } 1 \\
\text { gün }\end{array}$ & 1 gün \\
\hline $\begin{array}{l}\text { Mabeyn Elektrik } \\
\text { Müdürü Raif Bey }\end{array}$ & 1 gün & $\begin{array}{l}\text { DülbendciMuhyiddin } \\
\text { Efendi adına oğulları }\end{array}$ & 1 gün \\
\hline
\end{tabular}




\begin{tabular}{|l|l|l|l|}
\hline & & tarafından 1 gün & \\
\hline
\end{tabular}

Kaynak:Himaye-i Etfal Cemiyeti Umumi Rapor ve Bilanço, 1338,s.22-23

Himaye-i Etfal Cemiyeti'nin iaşe masraflarını yukarıda belirttiğimiz kişiler 37 günlük suretle karşılamayı taahhüt etmişlerdir.

\section{Sonuç}

Himaye-i Etfal Cemiyeti ülkenin maddi manevi zor koşullarında faaliyete başlamış bir kurumdur. Ülke uzun süreli bir savaşa hazır değildi. Savaş ekonomisi koşullarında ülke açlık ve kıtlıkla mücadele ediyordu. Cepheye giden askerler geride kadınlar ve öksüz yetim çocukları bırakmışlardı. Bu dönem de ülkenin her yerinde aç, çaresiz durumda bulunan çocuklar bulunuyordu.

Kimsesiz kalan çocukları himaye etmek maksadı ile 1917 yılında Himaye-i Etfal Cemiyeti kurulmuştur. Cemiyet kısa sürede başta İstanbul olmak üzere ülkenin birçok yerinde şubeler açmıştır. Çocukları himaye etmenin yanında eğitimlerini de sağlamak için çeşitli kuruluşlar açılmıştır. Bu sayede meslek öğrenebilecek ve geleceklerini teminat altına alabileceklerdi.

Himaye-i Etfal Cemiyeti'nin Nizamnamesine göre bir bütçesi bulunuyordu. Ancak cemiyet yardıma muhtaç kimsesiz sayısının her geçen gün artması sebebi ile gelirleri yeterli olmamıştır. Bu sebeple cemiyet bağış, konser düzenlemiş, şahsi yardımlar almaya çalışmış yada beslenme ve yatak taahhüdünde bulunan hayırseverler sayesinde cemiyetin faaliyetlerini devam ettirmeye çalışmıştır.

Cemiyet ülkenin savaş yıllarında kimsesiz çocukları korumak, topluma kazandırılmak amacı ile kurulmuştur. Ülkenin maddi koşullarının tükenmiş olduğu zamanlarda sadece üyelerin yıllık taahhütleriyle hizmetlerini aksatmadan yerine getirmeye çalışmıştır. Zaman içerisinde çocukların durumları değerlendirilerek ihtiyaçları dahilinde yeni kurumlar açılmıştır. Cemiyet ülkenin zorlu koşullarında çocukları himaye etmek gibi ulvi bir amaçla kurulmuş ve ülkenin tüm

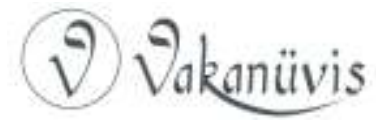


zorlu koşullarına rağmen yeni kaynaklar oluşturarak görevini başarıyla gerçekleştirmiştir.

\section{Kaynakça}

Deniz, Burcu, Dr. Fuad Umay ve Çocuk Esirgeme Kurumu Faaliyetleri, Kırklareli,2019

Eldem, Vedat, Harp ve Mütareke Yıllarında Osmanlı İmparatorluğunun Ekonomisi,Ankara:Türk Tarih Kurumu Basımevi,1994.

Himaye-i Etfal Cemiyet-i Umumiyesi, 24 Şubat 1338 tarihinde in'ikad edecek Meclis-i Umumide kıraat edilmek üzere Heyet-i Merkeziyece 16 Şubat 1338 tarihinde kabul edilmiş olan 1334 sene-i maliyesine mahsus senelik Umumî Rapor ve Bilanço, Dersaadet, Minber Matbaası, 1338.

Himaye-i Etfal Cemiyet-i Umumiyesi, 24 Şubat 1335 tarihinde in'ikad edecek Meclis-i Umumide kıraat edilmek üzere Heyet-i Merkeziyece 16 Şubat 1338 tarihinde kabul edilmiş olan 1335 sene-i maliyesine mahsus senelik Umumî Rapor ve Bilanço, Dersaadet, Minber Matbaası, 1335

Kapcl, Hikmet Zeki, " Osmanlı Eğitim Sisteminde Disiplin: Darülhayr-ı Ali Örneği ", Uluslar arası Sosyal Araştırmalar Dergisi,6/28(2013), s.169.

Kapcı, Hikmet Zeki, Osmanlıdan Cumhuriyete Yetim, İstanbul. Karataşer, Büşra " Konya Hamidiye Sanayi Mektebi", Kırklareli Üniversitesi iiBF Dergisi ,6/1(2017), s.127.

Karataşer, Büşra, 1914-1923 arası istanbul'un iaşesi ve ihtikar Sorunu, Nobel Yayıncilık,Ankara, 2019,s.47-98.

Karataşer, Büşra ,"Himaye-i Etfal Cemiyeti'nin Gelirleri Üzerine bir Değerlendirme", Tarih Araştırmaları, 35/3 (2020),s.551-568.

Karataşer, Büşra ,"Cost Of Living in Ottoman Empire during the armistice period: a case of istanbul, Journal of Emerging Economies and Policy, 2/1,2017,s.55

Maksudyan, Nazan, " Evli evine köylü köyüne, evli olmayan Osmanlı Kent Reformu ve Şehirlerde İstenmeyen Çocuklar", Kebikeç,34(2012),s.159.

Okay, Cüneyd,Belgelerle Himaye-i Etfal Cemiyeti: 1917-1923,İstanbul : Şule Yayınları, 1999

Özbek, Nadir, " II. Abdülhamid ve Kimsesiz Çocuklar Darülhayr-ı Ali, Tarih ve Toplum 182(1999), s.17.

Sarıkaya, Makbule "Savaş Yıllarında Himaye-i Etfal Cemiyeti'nin Çocuk Misafirhanesi ve Çocuklar", Atatürk Üniversitesi Atatürk ilkeleri ve İnkılâp Tarihi Enstitüsü Müdürlügü Atatürk Dergisi, 3/3, ( 2003),s.35

Sarıkaya, Makbule "Türkiye'de Zirai Eğitime Bir Örnek: Kalender Ziraat Yurdu", ActaTurcıca, Çevirimiçi Tematik Türkoloji Dergisi, 4/1( 2012),s.56

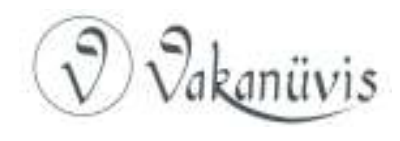


Sofuoğlu, Ebubekir Osmanlı Devletinde Yetimler için Alınan Bazı Sosyal Tedbirler, Savaş Çocukları öksüzler ve yetimler, İstanbul,2003.

Şeker, Kevser, Osmanlıdan Cumhuriyete Çocukların Korunması ve Çocuk Esirme Kurumu(1917-1981), İstanbul,2015,s.101

Toprak, Zafer, "Fuhuş" Dünden Bugüne İstanbul Ansiklopedisi, III,İstanbul,1994,s.345

Yerasimos, Stefanos, İstanbul 1914-1923, İstanbul, 1996. 